DRAŽEN CVITANIĆ, Ph.D.

E-mail: drazen.cvitanic@gradst.hr

University of Split, Faculty of Civil Engineering,

Architecture and Geodesy

Matice hrvatske 15, 21000 Split, Croatia
Traffic in the Cities

Preliminary Communication

Submitted: 8 Dec. 2016

Accepted: 28 June 2017

\title{
JOINT IMPACT OF BUS STOP LOCATION AND CONFIGURATION ON INTERSECTION PERFORMANCE
}

\begin{abstract}
There are several possible bus stop locations and config urations. A bus stop can be located before or after the intersection as curb-side stop, bus bay or bus bulb. Determining the proper configuration and location of bus stop represents an important planning decision. While previous research efforts in literature have suggested some advantages and disadvantages regarding bus stop locations and configurations, little effort has been made towards understanding the joint impact of bus stop location and configuration on the transit and other vehicle traffic performance on the intersection. So, this paper analyses the joint impact of bus stop location and configuration on the operational characteristics of traffic flow in terms of average bus trip time and control delay. These operational performance measures for various intersection layouts, volume distributions, movement splits, average bus dwell times and bus departure frequencies have been obtained using calibrated microsimulation traffic software.
\end{abstract}

\section{KEY WORDS}

bus stop; bay; bulb; intersection; control delay; microsimulation;

\section{INTRODUCTION}

There are several possible bus stops locations along the road. A bus stop can be located before or after the intersection as well as in the middle of the block. Also, there are a few design possibilities (configurations) such as curb-side stop, bus bay and bus bulb.

Decisions about the location and configuration of bus stops are expected to have a major impact on the average speeds i.e. delay of bus transit service [1, 2 ,
3]. In recognition of the importance of bus stop location and configuration Transit Cooperative Research Program (TCRP) report [4] presents guidelines for bus stop design, while discussing the advantages and disadvantages of each location and configuration. Other researchers have investigated the impacts of bus stop configuration on the average traffic speed [5] or the impacts of bus stop location on bus stop time [6]. Research [5] found that curb-side stop causes abrupt decrease of traffic speed for certain flow levels. Research [6] found that the use of far side stops decreases the bus stop time (to ca. 8\%).

Experimental study [7] analysed the influence of bus stop configuration on operations of bicycles, vehicles and buses. The results from research [8] showed that buses have better operational performance at curb-side stops than at bus bays in terms of average passenger boarding and alighting time as well as acceleration time.

So, choosing appropriate bus stop location and configuration is still a source of debate.

Consequently, there are many different guidelines regarding bus stops. According to the Croatian guidelines for intersection design [9] a bus stop should be generally located after the intersection because of pedestrian view. These bus stops can be designed as bus bay or curb-side stops as presented in Figure 1.

According to guidelines [9], a bus stop can be also located on the approach before the intersection as a bus bay (Figure 2) in case of synchronized signalized intersections or due to operational reasons.

As already mentioned, a bus stop can be located before (near side) or after (far side) the intersection.

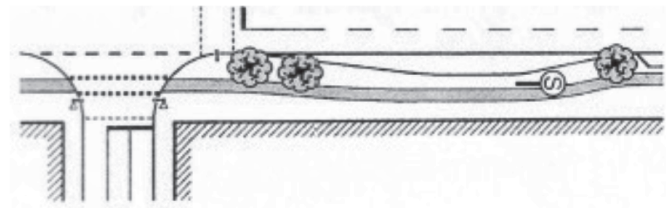

a) Bus bay after the intersection

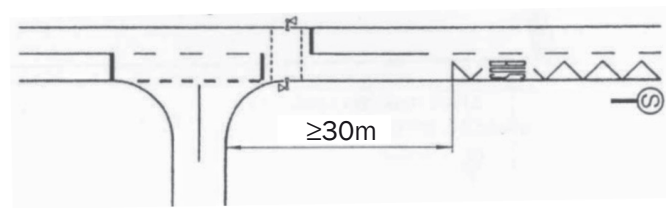

b) Curb-side stop

Figure 1 - Bus stop after the intersection [9] 


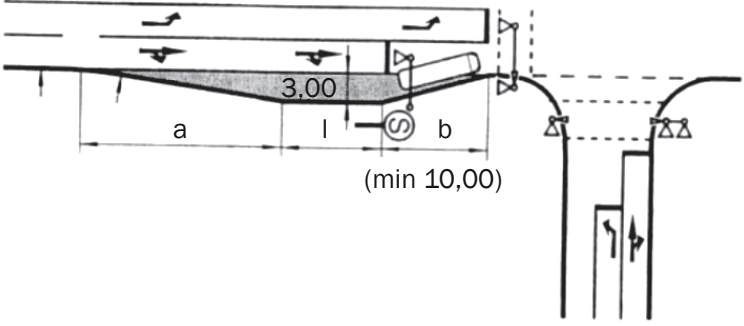

Figure 2 - Bus bay on the intersection approach [8]

Each location has some advantages and disadvantages [4] which are briefly summarized in Table 1.

Because of these advantages and disadvantages the guidelines $[4,10,11,12]$ specify how a bus stop can be located before or after the intersection according to each specific case, considering safety and operating elements that require on-site evaluation $[4,10]$ such as: passenger protection from passing traffic, access for people with disabilities, proximity to crosswalks and major trip generators, on-street automobile parking, bus routing patterns, volumes and turning movements of other traffic, sight distance problems, etc.

Besides configurations defined in Croatian guidelines, these guidelines $[4,10,11,12]$ still define a special design of bus stop on carriageway called bus bulb (NUB, curb extension) as shown in Figure 3. A bus bulb is an arrangement by which a sidewalk or pavement is extended outwards for a bus stop; typically, a bus bulb replaces the roadway that would otherwise be part of a parking lane.

Like the specific bus stop location, each bus stop configuration (bulb, curb-side and bay) has some advantages and disadvantages.

For example, bus bulb (Figure 3) allows buses to approach the curb in a straight line and precisely facilitates access for persons with restricted mobility, places the bus ahead of other traffic, helps keep the bus stop free of parked vehicles, requires a short length, provides additional sidewalk area and decreases the walking distance across the intersection, it is cheaper to construct than bus bay, etc.

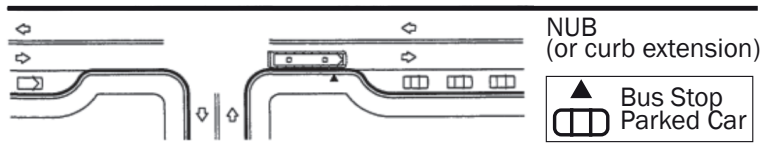

Figure 3 - Bus bulb layout [4]

On the other hand, a bus bulb can affect traffic flow of the other vehicles. The operational limits for bulbs should be derived from the motor traffic volume, the frequency of public transport vehicles and the dwell times [10, 13]. So, literature [10, 13] quotes: "With bus frequencies of 10 minutes and more, and with average stopping times of 16 seconds, bus bulbs are always possible. If stopping times are longer, or

Table 1 - Bus stop location advantages and disadvantages [4]

\begin{tabular}{|c|c|c|}
\hline & Advantages & Disadvantages \\
\hline Far side stop & 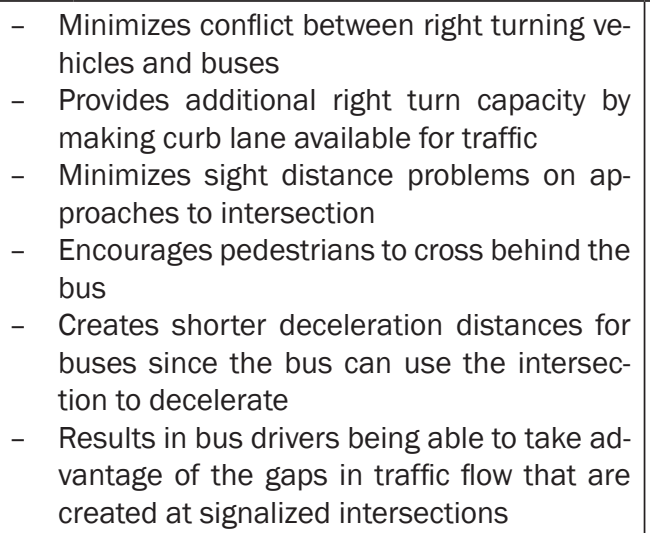 & 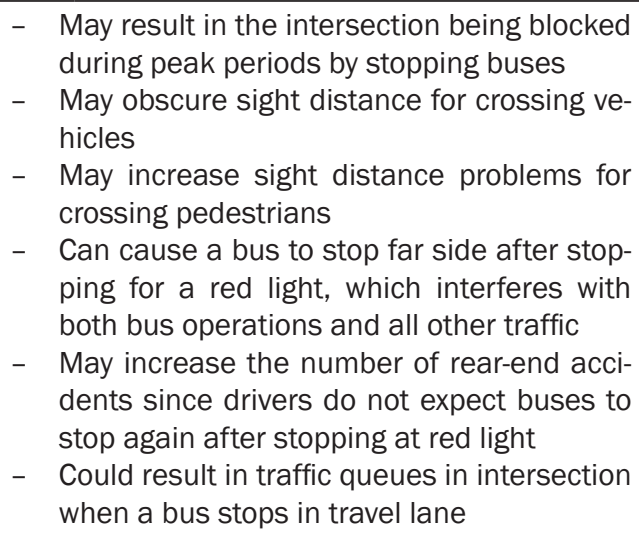 \\
\hline Near side stop & $\begin{array}{l}\text { - Minimizes interferences when traffic is } \\
\text { heavy on the far side of the intersection } \\
\text { - } \\
\text { Allows passengers to access buses closest } \\
\text { to crosswalk } \\
\text { - } \\
\text { Results in the width of intersection being } \\
\text { available for driver to pull away from curb } \\
\text { - Eliminates the potential of double stopping } \\
\text { - } \quad \text { Allows passengers to board and alight while } \\
\text { the bus stops at red light } \\
\text { - Provides driver with the opportunity to look } \\
\text { for oncoming traffic, including other buses } \\
\text { with potential passengers }\end{array}$ & $\begin{array}{l}\text { - } \quad \text { Increase conflict with right turning vehicles } \\
\text { - May result in stopped buses obscuring curb- } \\
\text { side traffic control devices and crossing pe- } \\
\text { destrians } \\
\text { - } \quad \text { May cause sight distance to be obscured } \\
\text { for cross vehicles stopped to the right of the } \\
\text { bus } \\
\text { - May block the through lane during peak pe- } \\
\text { riod with queuing buses } \\
\text { - Increases sight distance problems for cross- } \\
\text { ing pedestrians }\end{array}$ \\
\hline
\end{tabular}


frequencies are less than 10 minutes, bus bulbs present no problems up to a traffic volume of around 650 vehicles per hour in each direction on two-lane roads. Positive results have been reported at flows up to around 750 vehicles per hour in each direction, and at frequencies $\geq 10$ minutes".

Curb-side stops are similar to bus bulbs so they have similar characteristics. The main difference is that, when installed on the existing streets, the waiting areas are frequently not as wide as with a bus bulb, and the obstruction by parked motor vehicles is likely.

Bus bay has many disadvantages $[4,10,11]$ :

- many bays do not allow modern buses to stop close to the curb;

- bus drivers experience delays rejoining the traffic stream from the bay;

- they cannot always be approached accurately because of illegally parked vehicles at the roadside and in the bays which causes great problems for persons with restricted mobility and wheelchair users;

- standing passengers and those getting up to exit the bus are subject to unpleasant sideways forces as the bus approaches and exits;

- they require extra effort when winter maintenance is needed;

- their integration into the urban context is often problematic.

For these reasons bus bays are generally not recommended for typical urban streets with a $50 \mathrm{~km} / \mathrm{h}$ (or less) speed limit [11].

On the other hand bus bays may be required due to the volume of motor vehicle traffic or for operational reasons $[4,11]$. They are used, for example, where passengers wait for buses with long scheduled dwell times, as well as to reduce delay to other traffic while the bus is stopped.

From this short review of bus stops, it can be concluded how because of their advantages bus bulbs should be implemented as frequently and regularly as possible on urban streets. According to literature [10, 11], converting bus bays into bulbs can be regarded as generally improving the local traffic conditions on urban (built-up) streets with speeds of up to $50 \mathrm{~km} / \mathrm{h}$.

\section{PAPER OBJECTIVE}

From the review of guidelines and research papers it can be concluded that there were no comprehensive comparisons about operational characteristics (bus trip time, control delay and Level of service LOS) of traffic flows caused by joint effect of bus stop locations and configurations. Most of the research focuses on the impact of bus stop location $[3,6,8]$ or configuration $[5,7]$ on particular performance measure such as bus stop time, dwell time, bus delay and traffic speed. Literature $[10,13]$ gives some prerequisites, regarding bus frequencies, average stop time and intensity of traffic flow, when bus bulbs can be used on two-lane streets without detailed analysis of traffic operation on the intersection, but does not deal with joint impact of bus stop location and configuration on the intersection performance. So, this paper deals with the comparison of joint impact of bus stop location and configuration on operational characteristics of traffic flow in terms of average bus trip time and control delay at intersection.

The main objective of research is to establish traffic conditions for which bus bulbs or curb side stops can be used instead of bus bays on urban streets because bus bulbs generally improve the local traffic conditions [10].

The performance measures for various intersection layouts, volume distributions, movement splits, average bus dwell times and bus departure frequencies have been obtained using calibrated microsimulation traffic software.

\section{APPLIED METHODOLOGY AND ANALYSED CONFIGURATIONS}

Microsimulation traffic analysis tool TSIS 6 - CORSIM [14] was calibrated on local conditions [15] and used for analysing the average bus trip time and control delay on intersection approaches for analysed intersection layouts, bus stop locations and configurations. The control delay is the difference between the car travel time that would have occurred in the absence of the intersection control, and the travel time that results due to the presence of the intersection control. Bus trip time is the time needed for a particular bus to transverse the analysed segment of the main street (ca. $500 \mathrm{~m}$ ). Here the average values of control delay for all vehicles and the average trip time for all buses were analysed.

Figure 4 presents four analysed variants of bus stop locations and configurations at the intersection of twolane roads.

Variant 1a represents curb-side stop as well as bus bulb before the intersection; Variant $1 \mathrm{~b}$ represents bus bay before the intersection; Variant $1 \mathrm{c}$ represents curb-side stop (bulb) after the intersection; and Variant $1 d$ represents bus bay after the intersection.

All of these bus stop locations and configurations were analysed for different intersection layouts in terms of the number of continuous approach and departure lanes on the main street. So, these variants $(a, b, c, d)$ were analysed for intersections with one continuous lane on the main direction as presented in Figure 4; then for two continuous lanes on the main direction (for example Figure 5a represents Variant $2 \mathrm{a}$, and for three continuous lanes on the main street Figure 5 b represents Variant $3 a$ ).

Thus, four variants have been analysed with one continuous lane (variants $1 \mathrm{a}, 1 \mathrm{~b}, 1 \mathrm{c}, 1 \mathrm{~d}$ ), four 


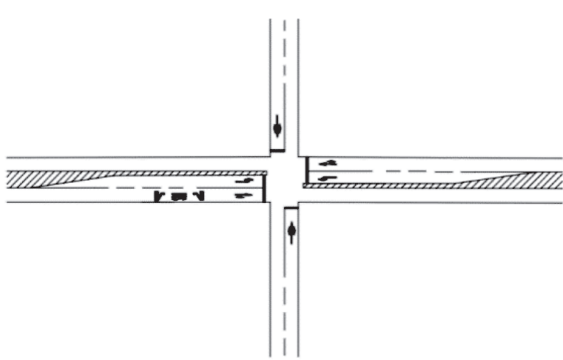

a) Variant $1 a$

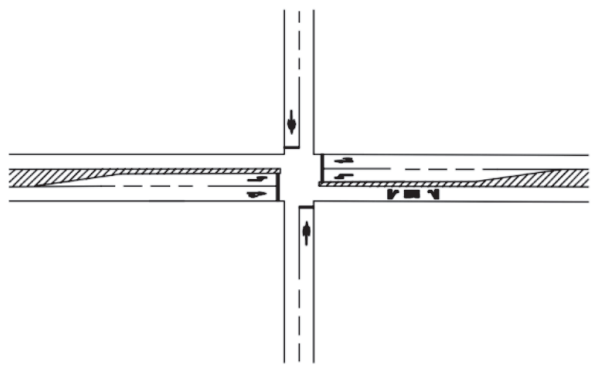

c) Variant $1 \mathrm{c}$

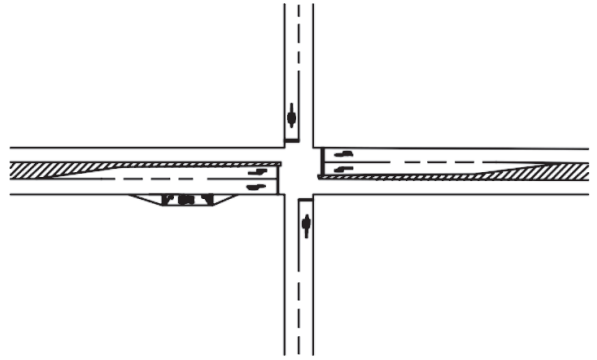

b) Variant $1 b$

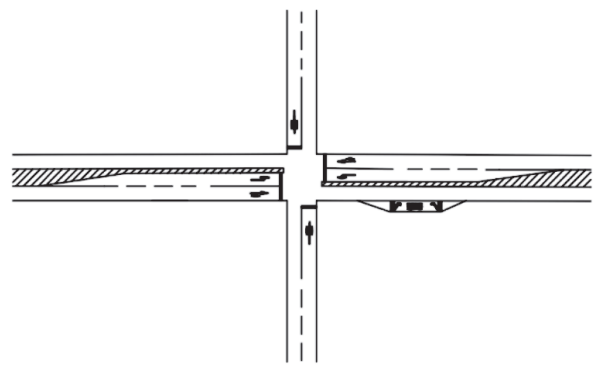

d) Variant $1 d$

Figure 4 - Analysed locations and configurations of bus stops

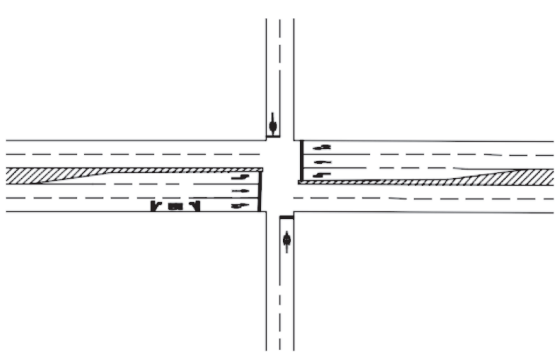

a) Variant $2 a$

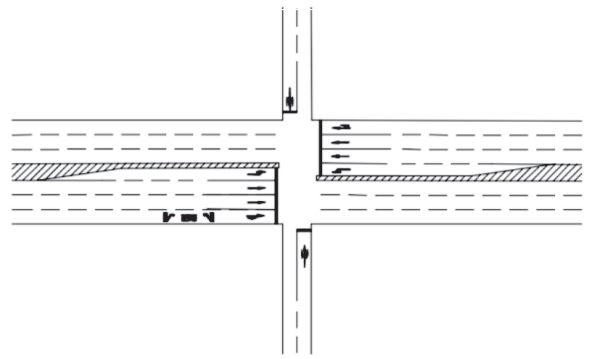

b) Variant $3 a$

Figure 5 - Analysed intersection layouts

variants with two continuous lanes $(2 \mathrm{a}, 2 \mathrm{~b}, 2 \mathrm{c}, 2 \mathrm{~d})$ and four variants with three continuous lanes on the main street (3a, 3b, 3c, 3d).

Each variant was modelled in TSIS defining the number of lanes, location and configuration of the bus stop. Figure 6 presents the resulting animation for variant $2 \mathrm{~b}$, i.e. two continuous lanes on the main street and bus bay before the intersection.

In order to describe various traffic conditions (from light traffic to intensive traffic at capacity level) huge range of traffic volumes, different movement splits, bus frequencies and dwell times were analysed.

Since it is not practical to conduct the analysis for all possible combinations of volumes, movement splits, bus frequencies, etc., here the representative values were analysed.

\section{Traffic volume}

The range of traffic volume was analysed, from low traffic volume (500 veh/h) with negligible impact of bus stop location and configuration on intersection performance (resulting LOS B for all variants) to high volumes at capacity level (LOS F) where bus stop location and configuration have significant impact on the intersection performance.

So, for variants with one continuous lane in the major street, the volume ranged from 500 to 1,000 vehicles per hour (veh/h).

For variants with two continuous lanes in the major street, the volume ranged from 500 to $1,700 \mathrm{veh} / \mathrm{h}$ with increment of $200 \mathrm{veh} / \mathrm{h}$.

Table 2 - Performance measures for Variant 1a

\begin{tabular}{||c|c|c||}
\hline \multicolumn{3}{||c||}{ 10-75-15 } \\
\hline \multicolumn{3}{|c||}{ Variant 1a } \\
\hline Q [veh/h] & $\begin{array}{c}\text { Average BUS trip } \\
\text { time [s] }\end{array}$ & $\begin{array}{c}\text { Control delay } \\
{[\text { s/veh] }}\end{array}$ \\
\hline 500 & 76.5 & 14.2 \\
\hline 600 & 77.5 & 15.8 \\
\hline 700 & 83.4 & 18.4 \\
\hline 800 & 89.4 & 25.5 \\
\hline 900 & 108 & 46 \\
\hline 1,000 & 142 & 85 \\
\hline
\end{tabular}




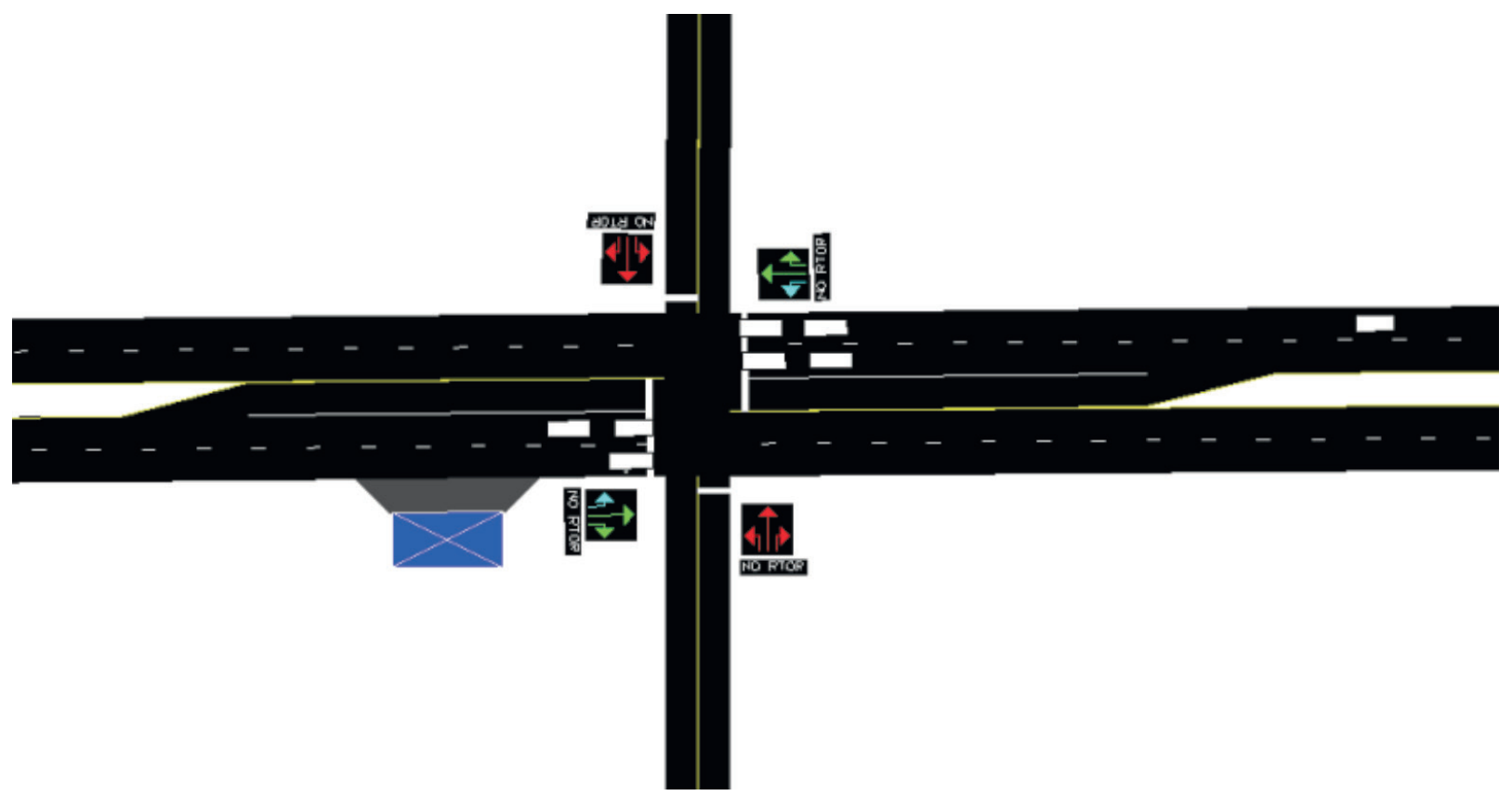

Figure 6 - Animation of variant $2 b$

Table 3 - Input traffic data

\begin{tabular}{|c|c|c|c|c|c|c|}
\hline VARIANTS & $\begin{array}{c}\text { Traffic volume } \\
\text { range } \\
\text { [veh/h] }\end{array}$ & Movement split & $\begin{array}{c}\text { Bus dwell } \\
\text { time [s] }\end{array}$ & $\begin{array}{l}\text { Cycle } \\
\text { length } \\
\text { [s] }\end{array}$ & $\begin{array}{c}\text { Phase lengths } \\
{[\mathrm{s}]}\end{array}$ & $\begin{array}{c}\text { Bus } \\
\text { frequency } \\
{[\mathrm{s}]} \\
\end{array}$ \\
\hline Variants $1 \mathrm{a}, 1 \mathrm{~b}, 1 \mathrm{c}, 1 \mathrm{~d}$ & $500-1,000$ & \multirow{3}{*}{$\begin{array}{c}10 \% \text { left; } 75 \% \text { through; } \\
15 \% \text { right turns } \\
\text { and } \\
15 \% \text { left; } 65 \% \text { through; } \\
20 \% \text { right turns }\end{array}$} & \multirow{3}{*}{$\begin{array}{l}15 \\
\text { and }\end{array}$} & \multirow{3}{*}{70} & \multirow[t]{3}{*}{ Major green: 35} & \multirow[t]{2}{*}{300} \\
\hline Variants $2 \mathrm{a}, 2 \mathrm{~b}, 2 \mathrm{c}, 2 \mathrm{~d}$ & $500-1,700$ & & & & & \\
\hline Variants $3 a, 3 b, 3 c, 3 d$ & $500-2,300$ & & & & & 600 \\
\hline
\end{tabular}

For variants with three continuous lanes in the major street the volume ranged from 500 to 2,300 veh/h with increment of $200 \mathrm{veh} / \mathrm{h}$.

Volume tables were developed with an increment of $100 \mathrm{veh} / \mathrm{h}$ as shown in Table 2 for Variant $1 \mathrm{a}$.

\section{Movement split}

For the purpose of research two common distributions of traffic volumes per movement were analysed:

1) $10 \%$ left; $75 \%$ through; $15 \%$ right turns,

2) $15 \%$ left; $65 \%$ through; $20 \%$ right turns.

\section{Bus dwell time}

Two common average dwell times at bus stops were analysed: 15 and 30 seconds.

\section{Bus frequency}

Two different headways between bus departures were analysed: 300 and 600 seconds.

\section{Cycle and phases length}

A general rule is that any cycle length in the range of 0.75 to 1.50 times the absolute minimum delay cycle length will have little impact on delay [16]. So in this paper the cycle length of 70 seconds was chosen because it adequately represents delays at intersection for the cycle lengths from 53 to $105 \mathrm{sec}$ onds which is a range of cycle lengths commonly used on urban streets with bus stops.

Cycle length of 70 seconds was analysed with 35 and 25 seconds of green phases on major and minor streets, respectively. Both phases have yellow time of 3 seconds and all red times of 2 seconds.

For variants with higher volume (more than $100 \mathrm{veh} / \mathrm{h}$ ) of left turners, which cannot pass as the sneakers [17], additional 8 seconds of protective left green light on the major street are added to the cycle length.

Each variant was simulated 15 times in order to achieve better statistical significance of average control delay and bus trip time values.

Table 3 shows input data for the conducted simulations.

\section{SIMULATION RESULTS}

Simulations results are presented on the graphs in Figures 7-9. 
It is worth mentioning that there is no separate analysis for bus bulbs because operational characteristics in terms of control delay and average bus trip time are equal as for the curb-side stop.

Analyses were conducted for bus dwell time of 15 seconds and bus departure headway of 600 seconds (Figures 7a-9a); then for dwell time of 30 seconds and departure headway of 600 seconds (Figures $7 b-9 b$ ); and finally for dwell time of 30 seconds and departure headway of 300 seconds (Figures 7c-9c).

On $Y$ axis are values of the average bus trip time and intersection approach control delay for analysed variants, while on $\mathrm{X}$ axis there are traffic volumes on the main street intersection approaches. Also, there are lines drawn in the graphs which show the threshold values for Levels of Service C, D and E according to Highway Capacity Manual [17].

Figure 7 shows simulation results for variants with one continuous lane in the main direction for different bus stop locations and configurations.

Variant 1a represents a curb-side stop as well as a bus bulb in front of the intersection; variant $1 \mathrm{~b}$ represents bay before the intersection; variant $1 \mathrm{c}$ represents curb-side stop (bulb) after the intersection; while variant $1 \mathrm{~d}$ represents bus bay after the intersection.

Figure $7 a$ presents the results for low frequency ( 6 buses per hour; i.e. headway of 600 seconds) bus routes and short average dwell time of 15 seconds which represents a common situation on less important transit streets.

It can be seen that variant $1 \mathrm{~b}$ has the largest average bus trip time for volumes up to 800 veh/h. The average trip time is 5 to $10 \%$ larger in comparison with other variants because bus drivers experience delay rejoining the traffic stream from the bay before the intersection. For volumes over $800 \mathrm{veh} / \mathrm{h}$ bus trip time for variant 1a (bus bulb or curb-side stop before the intersection) reaches similar values of bus trip time as variant $1 \mathrm{~b}$ because curb side-stop at higher volumes causes larger control delay than other variants increasing the trip time for all vehicles including buses. For longer dwell times and shorter bus departure headways (Figure 7c) variant 1c (curb-side stop or bulb after the intersection) has the same effect because vehicles waiting behind the bus propagate upstream and for higher volumes (>800 veh/h) they can block the intersection causing delay for all vehicles including buses.

Bus bay after the intersection has best performance in the sense of bus trip time and control delay for almost all combinations of volumes, bus departure headways and average bus dwell times.

In terms of control delay there is no significant difference between variants up to volumes of $800 \mathrm{veh} / \mathrm{h}$ and departure headways of 30 seconds (Figures $7 a$ and $7 b$ ). For larger volumes or shorter headways variants $1 \mathrm{a}$ and 1c (curb-side stops or bulbs before and after the intersection) have significant larger control delay in comparison with bus bays because vehicles have to wait in the lane behind the stopped bus. For variant 1a vehicles have to wait for bus departure from the bus stop before the intersection even in situations when they have green light on the traffic signal while for variant $1 \mathrm{c}$ vehicles waiting behind the stopped bus propagate upstream and block the intersection causing delay.

So, for a volume of $800 \mathrm{veh} / \mathrm{h}$ all variants have LOS C; for a volume of 900 veh/h variants with bays (1b and $1 \mathrm{~d}$ ) have LOS $\mathrm{C}$ for all dwell times and bus departure headways; while variants with curb-side stop or bulb (1a and 1c) have LOS D and LOS E for bus departure headway of 600 and 300 seconds, respectively. At volumes over 950 veh/h all variants have LOS E, i.e. they achieve approach capacity.

Thus, as frequency and dwell times increase, variants $1 \mathrm{a}$ and $1 \mathrm{c}$ have more intensive increase in control delay in comparison with other variants because there are more and more cycles where private cars have to wait behind the bus although they have green traffic signal or they are waiting behind the bus blocking the upstream intersection.

From the presented results it can be seen how traffic volume of $800 \mathrm{veh} / \mathrm{h}$ represents the threshold value for variants $1 \mathrm{a}$ and $1 \mathrm{c}$ in terms of satisfying the level of service $(C)$ for all analysed combinations of bus frequencies and dwell times. For higher traffic volumes there is intense increase of control delay in comparison with other two variants.

Also, it can be seen that the value of $800 \mathrm{veh} / \mathrm{h}$ represents a point where all variants start to change the intensity of increase of control delay and bus trip time i.e. the traffic flow becomes unstable as it approaches the capacity limit. So, it can be concluded that bus location on a carriageway (bus bulb or curb-side stop) is not equally usable as variants with bays just for the volume range between $800-950$ veh/h i.e. for volumes higher than $85 \%$ of capacity limit. For less intensive traffic there is no significant difference in performance measures between the analysed variants so that other reasons (operational and safety) should be the deciding factors for bus stop location and configuration. Just in case of higher bus frequencies and longer dwell times (Figure $7 \mathrm{c}$ ) the threshold volume value decreases to $700 \mathrm{veh} / \mathrm{h}$.

Figure 8 shows simulation results for variants with two continuous lanes in the main direction for different bus stop locations and configurations.

Variant 2b (bus bay before the intersection) results in the largest bus trip times for almost all volumes, bus departure headways and dwell times, but with somewhat less difference than in variants with one 


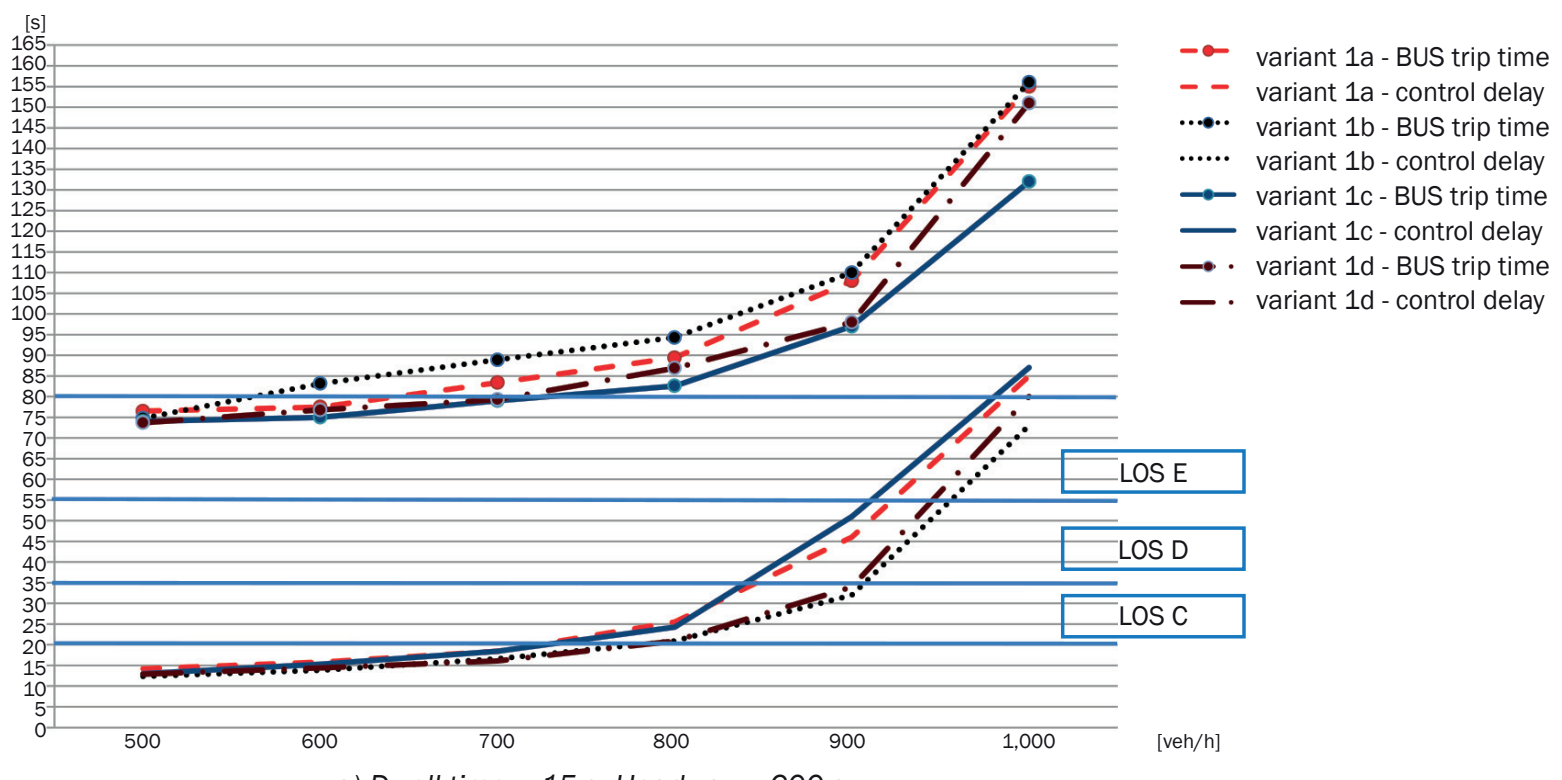

a) Dwell time $=15 \mathrm{~s} ;$ Headway $=600 \mathrm{~s}$
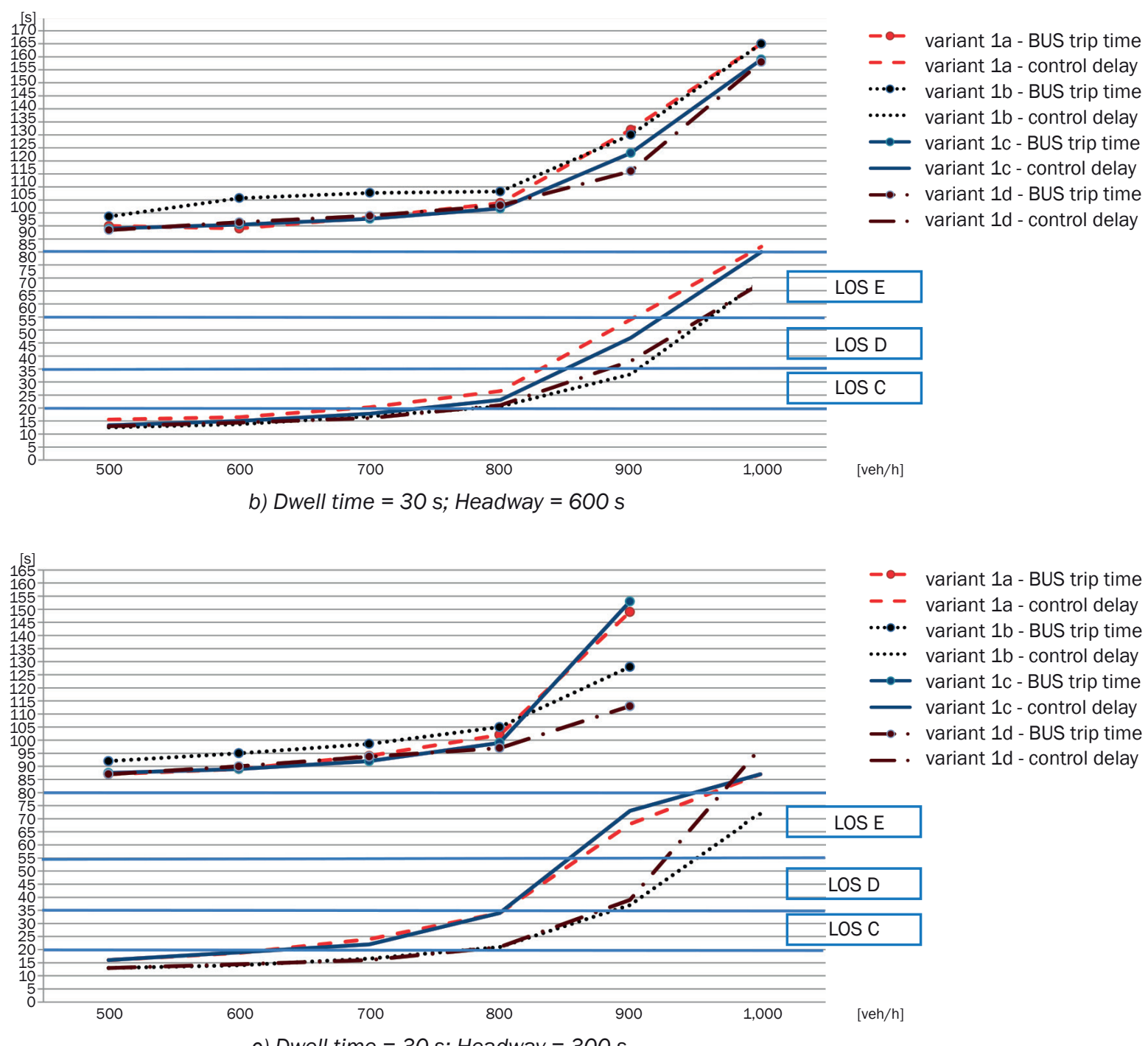

Figure 7 - Variants $1 a, 1 b, 1 c, 1 d$ 
continuous lane in the main street (Figure 7a-c). Just for volumes over 1,300 veh/h variant $2 a$ results in larger trip time because many vehicles have to wait behind the stopped bus.

Other three variants have similar bus trip times for volumes of up to 1,300 veh/h where variants at curbside stop (or bulbs) have somewhat larger bus trip times.

In terms of control delay all variants result in almost same delay for volumes under $1,300 \mathrm{veh} / \mathrm{h}$. At volume of 1,300 veh/h all variants experience significant increase in control delay, but variants with bus stop at curb-side or bulb (variants $2 \mathrm{a}$ and $2 \mathrm{c}$ ) have somewhat more intensive increase in comparison with variants with bus bay (variant $2 \mathrm{~b}$ and $2 \mathrm{~d}$ ).

It can be seen that for these variants the differences in control delay and bus trip time for volumes over the critical volume are less than in case of variants with one continuous lane (Figure 7). For volumes of over $1,300 \mathrm{veh} / \mathrm{h}$ the difference in control delay increases as bus departure headway decreases (Figure 8c).

For the volume of 1,300 veh/h all variants result in intersection approach LOS B, for volumes of 1,400 veh/h variants $2 a$ and $2 c$ result in LOS D, while other two have LOS C. At a volume of 1,500 veh/h all variants have LOS D except for the case with bus departure headway of 300 seconds where variants 1 a and $1 \mathrm{c}$ have LOS E. At a volume of 1,550 veh/h all variants result in LOS E, i.e. intersection approaches operate at capacity level for all analysed dwell times and bus departure headways.

It can be seen that the volume of 1,300 veh/h represents a point where all variants start to change the intensity of increase of control delay and bus trip time, but variants $2 \mathrm{a}$ and $2 \mathrm{c}$ have somewhat more intensive increase i.e. traffic flow becomes unstable for lower volumes than in variants $2 \mathrm{~b}$ and $2 \mathrm{~d}$. The volume of $1,400 \mathrm{veh} / \mathrm{h}$ represents a point where there is significant difference of control delay between the variants.

So, it can be concluded that bus location on carriageway (bus bulb or curb-side stop) is not equally usable as variants with bays just for the volume range between 1,400-1,550 veh/h i.e. for volumes higher than $85 \%$ of the capacity limit. For less intensive traffic there are no significant differences in the performance measures between the analysed variants, so other reasons (operational, safety) should be the deciding factors for bus stop location and configuration.

Figure 9 presents the simulation results for variants with three continuous lanes in the main direction.

For these configurations, variant $3 b$ results in the largest bus trip time for all volumes, dwell times and departure headways. At volumes higher than 1,300 veh/ $h$ the bus trip time becomes significantly larger than at other variants which have similar values for all analysed volumes, dwell times and headways.
In the sense of control delay all variants result in similar values.

\section{DISCUSSION}

Generally, in terms of bus trip time, variants with bus bay in front of intersection (variants 1b, 2b, 3b) achieve the largest values at all intersection layouts for almost whole range of traffic volumes, dwell time and bus departure headways. However, the difference in bus trip times is significant just for intersection layouts with three continuous lanes and volumes higher than $1,300 \mathrm{veh} / \mathrm{h}$.

In terms of control delay the variants with curb-side stop or bulb (variants a and c) result in larger control delay than variants with bus bay (variants $b$ and $d$ ). The difference in control delay between variants is insignificant under specific critical volumes.

For intersection layouts with one continuous lane (Figure 7) the critical volume is $800 \mathrm{veh} / \mathrm{h}$ per direction (700 in case when bus departure headway is 300 seconds). These are very similar results as in literature $[10,13]$ for two lane roads.

For variants with two continuous lanes in the main direction the critical volume is $1,300 \mathrm{veh} / \mathrm{h}$. For intersection layouts with three lanes in the main direction there is no critical volume, i.e. all variants have similar values of control delay. These values represent more than $85 \%$ of capacity limit i.e. traffic flow becomes extremely unstable for all variants and layouts. So, because of the shortcomings of the bus bays mentioned in Section 1, curb-side stop or even better bus bulb should be implemented as frequently and regularly as possible on the urban streets [10] for suitable traffic conditions.

So, for the streets with one continuous lane in the main direction, variant $1 \mathrm{a}$ and $1 \mathrm{c}$ (curbside stop or bulb before the intersection) should be used instead of bus bay for volumes under $800 \mathrm{veh} / \mathrm{h}$ and headways of over 600 seconds (Figures $7 a$ and $7 b$ ). The difference in bus trip time between variants with bulb and bay is negligible and LOS of intersection approach for all variants is $\mathrm{C}$ with maximum difference in control delay less than 5 seconds. Converting bulbs into bus bay is reasonable just for volumes in a range of 850950 veh/h i.e. near the capacity limit (i.e. at volumes of over 950 veh/h all variants have unsatisfactory LOS E). By increasing the bus frequency, variants $1 \mathrm{a}$ and $1 \mathrm{c}$ result in higher differences in control delay in comparison with other variants, so the threshold volume for using these variants decreases to 700 veh/h, where the difference in control delay in comparison with variant $1 \mathrm{~b}$ is 8 seconds and the intersection approach LOS is $\mathrm{C}$ (Figure $7 \mathrm{c}$ ).

For streets with two continuous lanes in the main direction, all analysed variants can be equally used in 


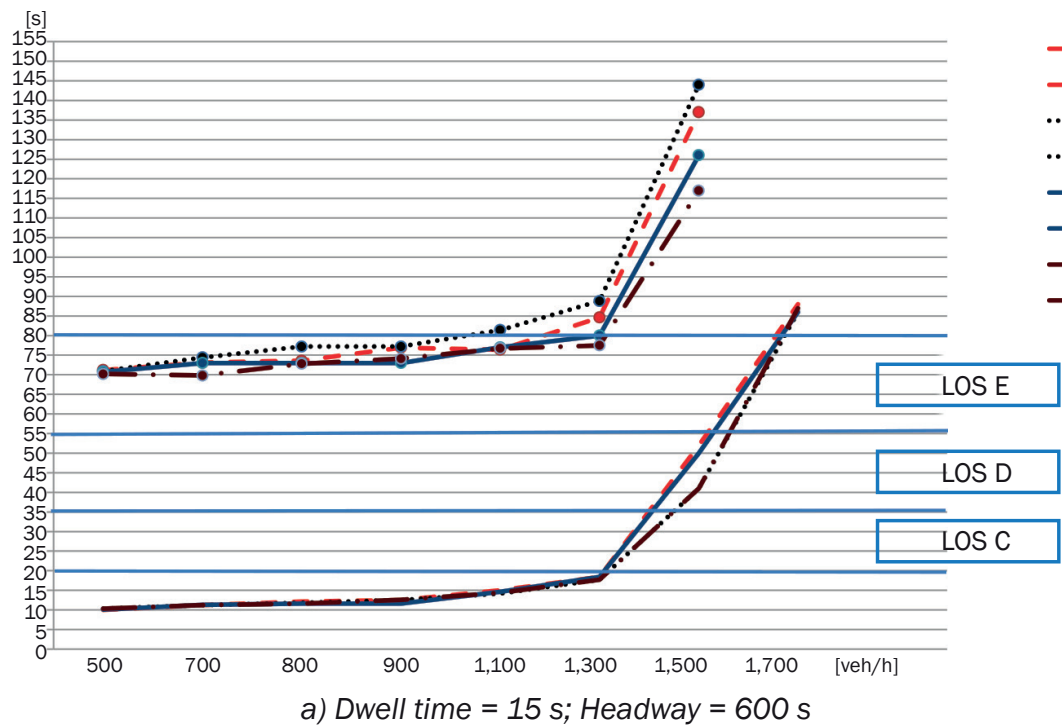

- o variant $2 \mathrm{a}$ - BUS trip time

- variant $2 \mathrm{a}$ - control delay

$\cdots \cdot$ variant $2 b-$ BUS trip time

...... variant $2 \mathrm{~b}$ - control delay

$\longrightarrow$ variant $2 \mathrm{c}$ - BUS trip time

- variant $2 \mathrm{c}$ - control delay

-. variant $2 \mathrm{~d}$ - BUS trip time

- variant $2 d$ - control delay

a) Dwell time $=15 \mathrm{~s} ;$ Headway $=600 \mathrm{~s}$

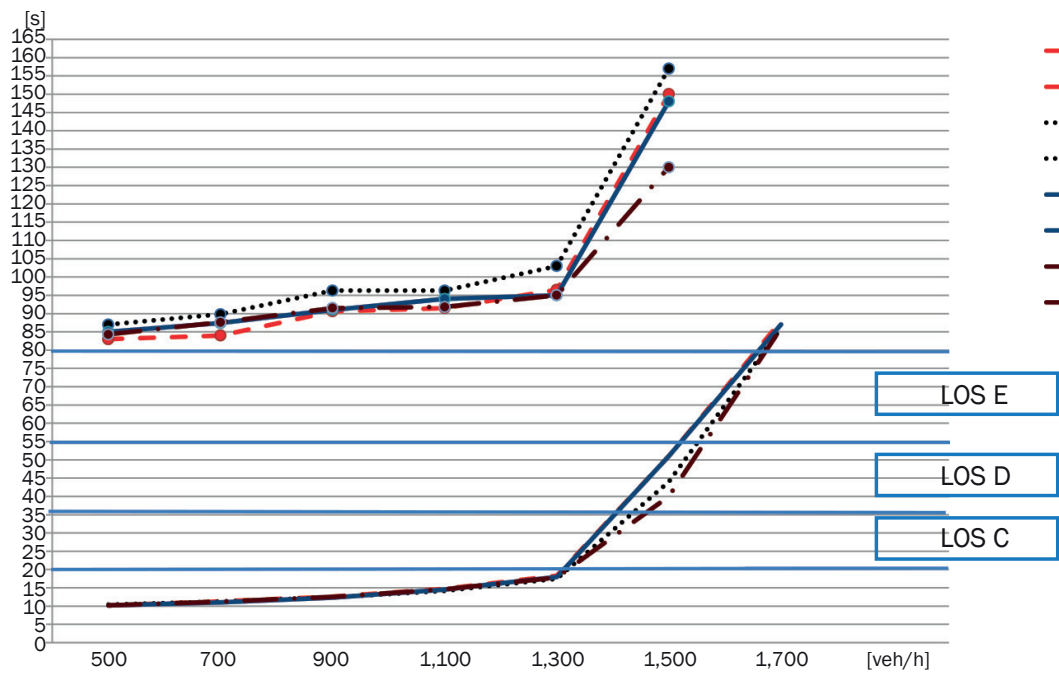

- - variant $2 \mathrm{a}$ - BUS trip time

- - variant $2 a$ - control delay

..... variant $2 b$ - BUS trip time

..... variant $2 \mathrm{~b}$ - control delay

- - variant $2 \mathrm{c}$ - BUS trip time

— variant $2 \mathrm{c}$ - control delay

- - variant $2 \mathrm{~d}$ - BUS trip time

- - variant $2 d$ - control delay

b) Dwell time $=30 \mathrm{~s}$; Headway $=600 \mathrm{~s}$

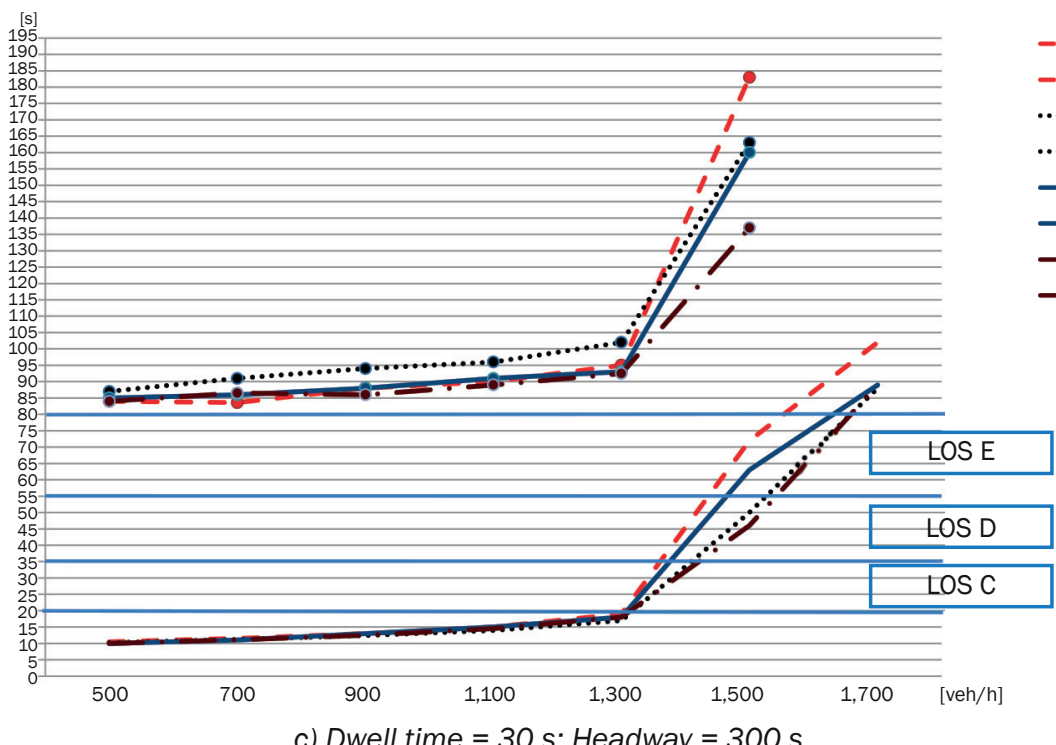

-o variant $2 \mathrm{a}$ - BUS trip time

- - variant 2a - control delay

.... variant $2 b$ - BUS trip time

...... variant $2 b$ - control delay

- - variant 2c - BUS trip time

— variant $2 \mathrm{c}$ - control delay

- - variant $2 \mathrm{~d}$ - BUS trip time

- - variant $2 \mathrm{~d}$ - control delay

Figure 8 - Variants 2a, 2b, $2 c$ 


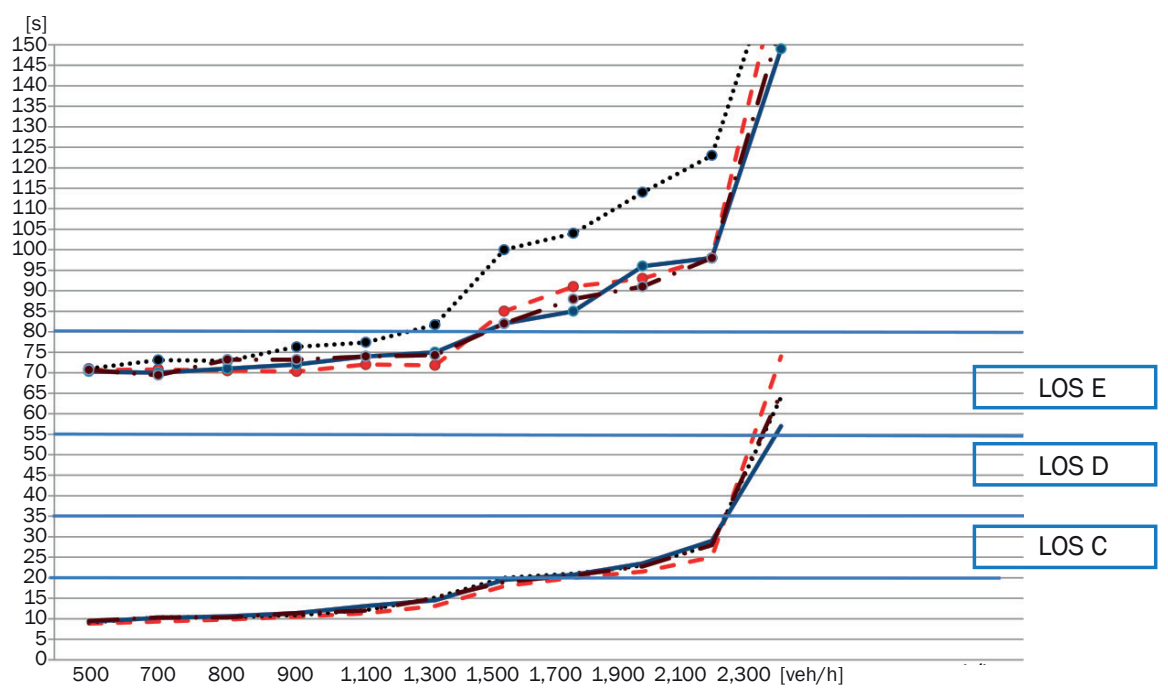

- - variant $3 a$ - BUS trip time

- variant 3a - control delay

..... variant $3 b$ - BUS trip time

...... variant $3 b$ - control delay

$\longrightarrow$ variant $3 c$ - BUS trip time

_ variant $3 c$ - control delay

- - variant $3 d$ - BUS trip time

- variant $3 d$ - control delay

a) Dwell time $=15 \mathrm{~s}$; Headway $=600 \mathrm{~s}$

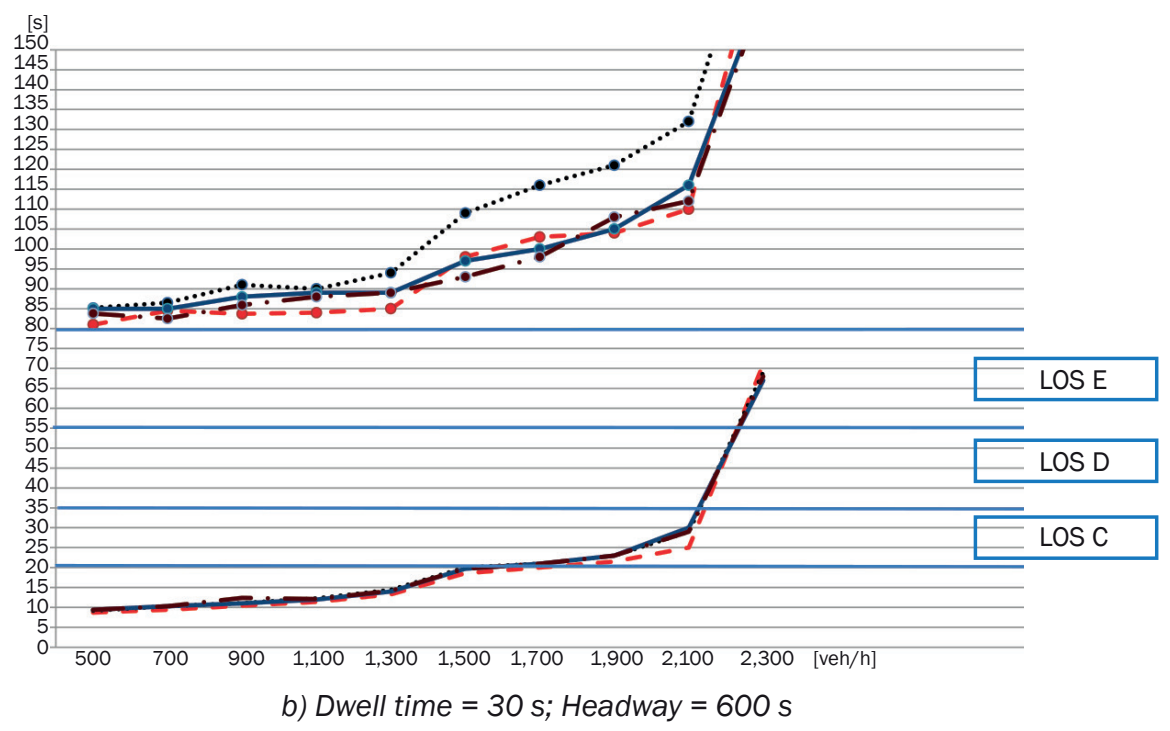

- - variant 3a- BUS trip time

- - variant $3 a$ - control delay

..... variant $3 b$ - BUS trip time

..... variant $3 \mathrm{~b}$ - control delay

$\rightarrow$ variant $3 \mathrm{c}$ - BUS trip time

_ variant $3 \mathrm{c}$ - control delay

-. variant 3d - BUS trip time

- variant 3d - control delay

b) Dwell time $=30 \mathrm{~s}$; Headway $=600 \mathrm{~s}$

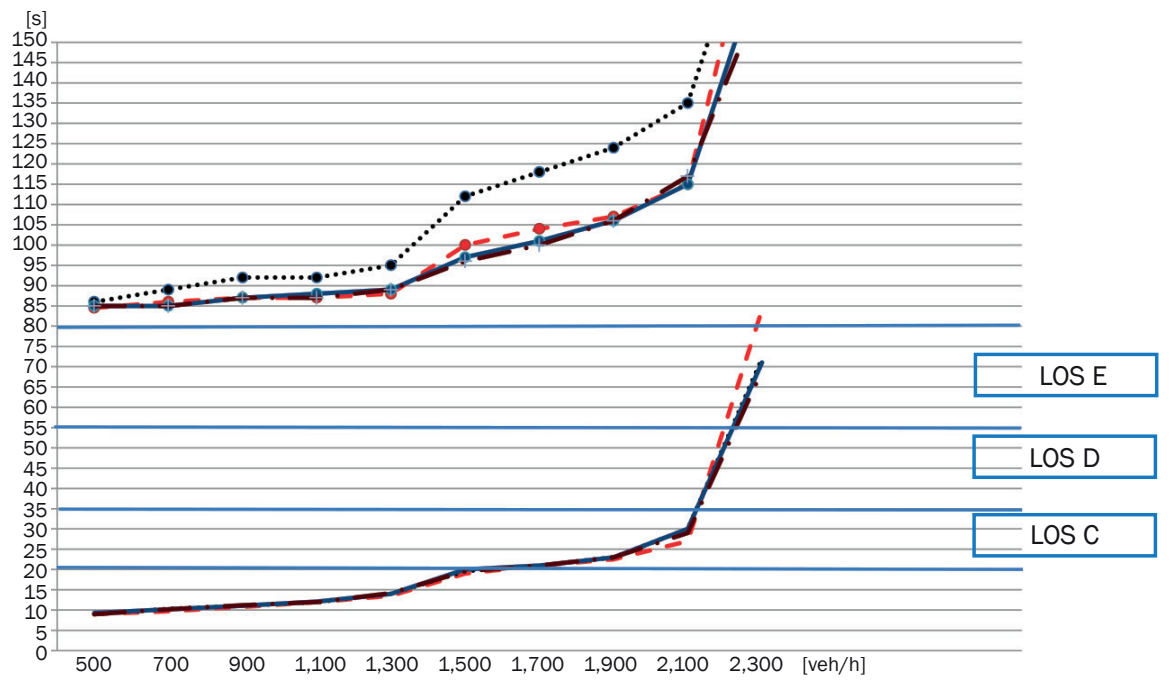

- o- variant $3 a$ - BUS trip time

- - variant $3 a$ - control delay

..... variant $3 b$ - BUS trip time

...... variant $3 \mathrm{~b}$ - control delay

-— variant $3 \mathrm{c}$ - BUS trip time

_ variant $3 \mathrm{c}$ - control delay

- . variant 3d - BUS trip time

- - variant $3 d$ - control delay

c) Dwell time $=30$ [s]; Headway $=300[\mathrm{~s}]$

Figure 9 - Variants $3 a, 3 b, 3 c, 3 d$ 
the sense of control delay for all volumes lower than $1,300 \mathrm{veh} / \mathrm{h}$ as well as for all the analysed dwell times and bus departure headways. Bus bays have better performance for volumes in the range of 1,300-1,550 while for volumes over $1,550 \mathrm{veh} / \mathrm{h}$, all variants reach LOS E, i.e. capacity limit.

For streets with three lanes in the main direction, all variants can be used equally over the whole analysed range of volumes, dwell times and bus headways, except variant $3 \mathrm{~b}$ which has significantly larger bus trip time for volumes over 1,300 veh/h.

So, the general conclusion of research is that converting bus bays into bulbs (because of many advantages) on urban (built-up) streets, with speed limit of up to $50 \mathrm{~km} / \mathrm{h}$, can be regarded as generally improving local traffic conditions [10] for almost the whole range of analysed traffic volumes, average bus trip times and departure headways.

Bus bays on urban streets with speeds of less than $50 \mathrm{~km} / \mathrm{h}$ may be required due to the high traffic volume (demand volume/capacity over $85 \%$ ) near capacity limit or at locations where passengers wait for buses with long scheduled dwell times.

\section{CONCLUSION}

This research has resulted in a range of traffic conditions (volumes, bus dwell times and headways) for which various variants of bus stop location and configuration could be used.

Regarding bus trip time, variants with bus bay in front of intersection achieve the largest values at all intersection layouts for almost whole range of traffic volumes, dwell times and bus departure headways. However, the difference in bus trip times is significant just for the layouts with three continuous lanes and volumes higher than 1,300 veh/h.

In terms of control delay, the variants with curb-side stops or bulb result in larger control delay than variants with bus bay. The difference in control delay between variants is insignificant under specific critical volumes. For layouts with one continuous lane the critical volume is $800 \mathrm{veh} / \mathrm{h}$ per direction (700 in case when bus departure headway is 300 seconds). For variants with two continuous lanes in the main direction the critical volume is $1,300 \mathrm{veh} / \mathrm{h}$. For variants with three lanes in the main direction there is no critical volume, i.e. all variants have similar values of control delay.

From the research results it can be concluded how bulbs or curb-side stops can be used instead of bus bays on urban (built-up) streets for almost whole range of volumes under the capacity level. Bus bulb has advantages over curb side stop because sidewalk is extended outwards for a bus stop, so pedestrians have more place and higher quality of service.
In choosing the appropriate location (before or after the intersection) in addition to the traffic conditions, safety requirements, shown in Table 1, for each specific case should be taken into account.

\section{Dr. sc. DRAŽEN CVITANIĆ}

E-mail: drazen.cvitanic@gradst.hr

Sveučilište u Splitu, Fakultet građevinarstva, arhitekture i geodezije

Matice hrvatske 15, 21000 Split, Hrvatska

\section{ZAJEDNIČKI UTJECAJ LOKACIJE I KONFIGURACIJE AUTOBUSNOG STAJALIŠTA NA OPERATIVNE KARAK- TERISTIKE RASKRIŽJA}

\section{SAŽETAK}

Postoji više mogućnosti izbora lokacije i konfiguracije autobusnog stajališta. Stajalište se može izvesti prije ili poslije raskrižja kao ugibalište, na prolaznom kolniku ili izvesti kao takozvani "bus bulb". Izbor odgovarajuće lokacije i konfiguracije stajališta predstavlja važnu odrednicu planiranja prometa u gradu. Dosadašnja istraživanja pretežito su obrađivala i sugerirala određene prednosti i mane lokacije ili konfiguracije stajališta, a manje su obrađivala zajednički utjecaj lokacije i konfiguracije stajališta na kvalitetu odvijanja javnog i privatnog prijevoza na raskrižju. Stoga se $u$ predmetnom članku analizira zajednički utjecaj lokacije $i$ konfiguracije stajališta na kvalitetu odvijanja prometa na raskrižju u pogledu prosječnog trajanja putovanja autobusa i prosječnog čekanja vozila na raskrižju. Navedene mjere efikasnosti odvijanja prometa su proračunate, korištenjem kalibriranog mikrosimulacijskog programa, za različite geometrije raskrižja, veličine $i$ raspodjele prometa, prosječna zadržavanja autobusa na stajalištu te različite učestalosti dolazaka autobusa na stajalište.

\section{KLUČNE RIJEČI}

autobusno stajalište; ugibalište; bulb; raskrižje; prosječno zakašnjenje; mikrosimulacija;

\section{REFERENCES}

[1] U.S. Department of Transportation. Stops, spacing, Iocation and design. Washington,D.C.; 2014. Available from: http://www.fta.dot.gov/12351_4361.html\#TCRP

[2] Giannopoulos G. Bus planning and operation in urban areas: A practical guide. Gower Pub Co United Kingdom; 1989.

[3] Furth P, SanClemente J. Near Side, Far Side, Uphill, Downhill: Impact of Bus Stop Location on Bus Delay. Transportation Research Record: Journal of the Transportation Research Board. 2006;1971(1):66-73.

[4] Transit Cooperative Research Program TCRP Report 19. Guidelines for the Location and Design of Bus Stops. Transportation Research Board. Washington, DC: National Academy Press; 1996.

[5] Koshy R, Arasan V. Influence of Bus Stops on Flow Characteristics of Mixed Traffic. Journal of Transportation Engineering. 2005;131(8):640-643.

[6] Diab E, El-Geneidy A. The far side story: Measuring the 
benefits of bus stop location on transit performance. Transportation Research Record. 2015;2538:1-10.

[7] Transportation Research Board, 94th Annual Meeting Compendium of Papers. Influences of Various Types of Bus Stops on Traffic Operations of Bicycles, Vehicles, and Buses; 2015.

[8] Liu XD, Yang Y, Meng M, Rau A. Impact of Different Bus Stop Designs on Bus Operating Time Components. Journal of Public Transportation. 2017;20(1):104-118.

[9] Smjernice za projektiranje raskrižja u naseljima sa stajališta sigurnosti prometa. Fakultet prometnih znanosti Sveučilišta u Zagrebu, Hrvatske ceste d.o.o., Zagreb; 2004.

[10] Directives for the Design of Urban Roads RASt 06. Forschungsgesellschaft für Straßen- und Verkehrswesen e.V. Köln: FGSV-Verlag; 2012.

[11] Roads Service, Transportation Unit. Bus stop design guide; 2005.

[12] Bus Priority Team Transport for London. Accessible bus stop design guidance; 2006.

[13] FGSV 299: HBS - Handbuch für die Bemessung von Straßenverkehrsanlagen, Ausgabe; 2015.

[14] University of Florida. Traffic Software Integrated System - Corridor Simulation TSIS 6.3 - CORSIM.

[15] Cvitanić D, Breški D, Lovrić I. Possibility of Microsimulation Models Calibration - Case Study in the City of Split. Promet - Traffic \& Transportation. 2012;24(3):231-241.

[16] Roess RP, Prassas ES, William RM. Traffic engineering. 3rd Edition. Pearson Prentice Hall; 2004.

[17] Transportation Research Board. Highway capacity manual HCM 2010. 